Human

Development
Psicologia: Teoria e Prática, 21(3), 418-436. São Paulo, SP, set.-dez. 2019. ISSN 1516-3687 (impresso), ISSN 1980-6906 (on-line). doi:10.5935/1980-6906/psicologia. v21n3p418-436. Sistema de avaliação: às cegas por pares (double blind review). Universidade Presbiteriana Mackenzie.

\title{
Autoscopy as a methodological resource in the interventions with autism: Empirical aspects
}

\author{
Carlo Schmidt ${ }^{1}$ \\ iD https://orcid.org/0000-0003-1352-9141 \\ Leila Regina O. de P. Nunes ${ }^{2}$ \\ (iD) https://orcid.org/0000-0003-2012-6973 \\ Thatyana M. Silva ${ }^{2}$ \\ (iD) https://orcid.org/0000-0001-8644-8305 \\ Jéssica Jaíne $M$. de Oliveira ${ }^{3}$ \\ iD https://orcid.org/0000-0003-4897-5889
}

To cite this paper: Schmidt, C., Nunes, L. R. P., Silva, T. M., \& Oliveira, J. J. M. (2019). Autoscopy as a methodological resource in the interventions with autism: Empirical aspects. Psicologia: Teoria e Prática, 21(3), 418-436. doi:10.5935/1980-6906/psicologia. v21n3p418-436

Submission: 12/04/2019

Acceptance: 07/06/2019

$(\mathrm{cc}) \mathrm{BY}$ The content of Psicologia: Teoria e Prática is distributed under the terms of the Creative Commons Attribution License.

1 Federal University of Santa Maria (UFSM), Santa Maria, RS, Brazil.

2 State University of Rio de Janeiro (Uerj), Rio de Janeiro, RJ, Brazil.

3 Santa Maria Integrated College (FISMA), Santa Maria, RS, Brazil. 


\begin{abstract}
Autoscopy is a methodological resource that includes video recording procedures with interventional practices, directing the analysis, and self-evaluation to the protagonists of this practice. The objective of this study is to present evidence of the effectiveness of the autoscopy procedure in autism interventions. Autoscopy was an independent variable in two of the experimental single-subject studies. Study A verified the effects of autoscopy on the teacher using pictographic cards to enhance student's communication and waiting for students' responses after their requests . Study B analyzed the effect on the socio-communicative abilities of the mother of the child and the child during the intervention. It was concluded that the responses of the teachers, just as much as the parents, showed significant statistical effects by the autoscopy, attesting to its robustness. The change in the participants' behavior wielded by the autoscopy is discussed.
\end{abstract}

Keywords: autism; methodology; intervention; autoscopy; experimental design.

\title{
AUTOSCOPIA COMO RECURSO METODOLÓGICO EM INTERVENÇÕES COM AUTISMO: ASPECTOS EMPÍRICOS
}

\section{Resumo}

A autoscopia é um recurso metodológico que inclui procedimentos de videogravação de práticas interventivas, visando a análise e a autoavaliação por um ou mais protagonistas dessa prática. O objetivo deste estudo foi apresentar evidências de eficácia do procedimento da autoscopia em intervenções com autismo. A autoscopia é utilizada como variável independente em dois estudos experimentais intrassujeitos. $\mathrm{O}$ estudo A verificou o efeito da autoscopia sobre os comportamentos de duas professoras que buscavam favorecer a comunicação do aluno com o uso de cartões pictográficos e aguardavam resposta deles após suas solicitações. Já o estudo B analisou o efeito sobre as habilidades sociocomunicativas da mãe de uma criança com autismo e seu filho durante uma intervenção. Concluiu-se que tanto as respostas das professoras quanto a dos pais mostraram efeitos estatisticamente significativos da autoscopia, atestando sua robustez. A mudança nos comportamentos dos participantes exercido pela autoscopia é discutida.

Palavras-chave: autismo; metodologia; intervenção; autoscopia; estudo experimental. 


\section{AUTOSCOPIA COMO RECURSO METODOLÓGICO EN INTERVENCIONES CON AUTISMO: ASPECTOS EMPÍRICOS}

\section{Resumen}

La autoscopia es un recurso metodológico que incluye procedimientos de vídeo con prácticas de intervención, dirigiendo el análisis y la auto-evaluación a los protagonistas de esta práctica. El objetivo de este estudio es presentar evidencia de la efectividad del procedimiento de autoscopia en intervenciones de autismo. La autoscopia se utiliza como una variable independiente en dos de los estudios experimentales. El Estudio A verificó los efectos de la autoscopia en el maestro usando tarjetas pictográficas para mejorar la comunicación del estudiante y esperar las respuestas después de sus solicitudes. El estudio B analizó el efecto sobre las habilidades socio-comunicativas de la madre del niño y del niño durante la intervención. Se concluyó que las respuestas de los profesores, tanto como los padres, mostraron efectos estadísticos significativos por la autoscopia, lo que demuestra su solidez. Se discute el cambio en el comportamiento de los participantes manejado por la autoscopia.

Palabras clave: autismo; metodología; intervención; autoscopia; estudio experimental.

\section{Introduction}

Autism spectrum disorder (ASD) is a condition that affects communication and social interactions and includes restrictive and repetitive behaviors and interests (American Psychiatric Association, 2013). These characteristics emerge precociously in infantile development and can interfere significantly in schooling using preference for solitary activities, difficulties in engaging in groups during recess, or in participating in activities and playing interactive games of catch or hide and seek (Schmidt \& Bittencourt, 2019). Such difficulties, either behavioral or communicative, need the mediation of the teacher so that these factors do not become barriers to the students' participation and learning in school. Therefore, teachers of students with ASD are placed in a prominent role, especially concerning their training.

In the last few years, there has been significant research in the field of professional development training in Special Education. This research has revealed an inadequacy in the traditional model of transmitting applied information to practitioners. Furthermore, the traditional dichotomy of theory versus practice, which has prevailed in these teacher-training programs, has fundamentally adopted a more informative nature. Thus, the knowledge produced in the academy is opposed 
to that of which is conceived by the teacher, supported by his or her day-to-day experiences in the classroom, which further delineates the disconnection between theory and practice. As Zeichner (1994) suggests, the supposed distance between both is expressed as the divergence between the theory of the academic observer and the theory of the teacher in the classroom, rather than any inherent difference between theory and practice. Autism teacher-training programs have typically been implemented through short-term courses, in either a classroom-training setting or online correspondence courses, offered to a large number of teachers by the Department of Education (Pletsch \& Souza, 2017). The content is limited to diagnostic aspects of the syndrome, characteristics of students with ASD and superficial presentations of educational programs such as Applied Behavior Analysis (ABA) and Treatment and Education of Autistic and Communication -related Handicapped Children (TEACCH), amongst others. The opportunities in which these teachers have to express their knowledge and share their classroom practices with trainers are rare. One of the most recent trends in teacher training is the so-called reflective technique that involves the recognition that trainers, along with their peers, should perform an active role in the establishment of objectives and pedagogical procedures. Therefore, it is understood that teachers possess theories that can improve the development of a common baseline knowledge regarding good teaching practices. The concept of a reflective practitioner emphasizes the expertise that exists in the techniques of good teachers, which Schön (2000) called "knowledge in action". This finding suggests that the process of understanding and improving teaching techniques is not enough for teachers to familiarize themselves with the experiences of others, yet their reflection regarding their own classroom experiences is indispensable.

This reflective technique can include the use of autoscopy, also known as microteaching (Allan, 1986). Autoscopy is a methodological resource that includes a video recording of intervention practices intending to have one or more of the intervention agents analyze, self-confront, and self-evaluate their performance (Sadalla \& Larocca, 2004). International studies, conducted in the 1980 s and $1990 \mathrm{~s}$ pioneered the field and investigated the use of autoscopy in teacher training. These studies showed that observation and reflection regarding their practices could enhance teachers' abilities and competencies (Allan, 1986). In Brazil, autoscopy research focused on the following topics: affect in the teacher-student relationship 
(Tassoni, 2008), teacher training focused on teacher's pedagogical practices (Larocca, 2002; Tosta, 2006; Rosa-Silva, Lorencini Júnior, \& Laburú, 2009) and the teaching-learning process in children with intellectual disabilities (Campos \& Glat, 2016). These investigations were unanimous in pointing out the relevance of autoscopy as a technique in the production of knowledge concerning the phenomena under consideration.

The self-confrontation mechanism stands out due to its system of thought and execution, which is similar to autoscopy. The literature regarding self-confrontation suggests that this analysis has immense relevance to the teachers' occupation. In 1997, the linguist Daniel Faïta developed self-confrontation to stimulate the study of the activity of train conductors in Europe. Later, the method was refined by the psychologist Yves Clot, in his Clinic of Activity, in the context of Vygotsky's cultural-historical approach. Self-confrontation, in Clot's words, consists of a methodological mechanism aimed at investigating the workers' performance in order to broaden their range of actions and their ability to operate in their environments and on themselves. This procedure is proven to be useful not only as a means for the individuals to gain knowledge regarding their professions but also as a resource for these workers to transform their occupation with the researcher's assistance.

Consequently, when professionals are confronted with their occupational circumstances, they have the possibility of re-designing the utilized mechanism, employing cognitive processes and thus modifying their performance in the future. In Brazil, studies regarding self-confrontation have been conducted in stricto sensu graduate programs in Education since the 2000s. Such investigations have served primarily to collect data. However, they did not advance or contribute to effective change in the occupational activities of the participants (Perez \& Messias, 2013).

This study considers the possibility of using such self-analysis procedures suggested by the autoscopy and self-confrontation studies to promote changes in the intervention practices among children with ASD.

Interventional practices in Special Education and Psychology do not always prove themselves efficient in serving the target population. The use of effective educational strategies can make significant differences in the lives of these individuals and their family members. In this regard, the search for significant practices 
based on scientific evidence has become a trend in various human sciences. Despite the lively discussions about the differences in the ontological, epistemological and methodological foundations of the natural and human sciences, this paradigm has been gaining support in the field of education through the movement called "Evidence-Based Education (EBE)" (Chizzotti, 2015). Such practices are defined as "methods and techniques that may have satisfied rigorous scientific standards determined by multiple reviewers and that, when replicated in a consistent, valid, and reliable form, produce positive results" (Nunes \& Nunes Sobrinho, 2010, p. 298).

Literature has emphasized the use of group experiments with randomized samples and single-subject experiments to identify these practices. Horner et al. (2005) suggested three parameters to consider if educational interventions are based on scientific evidence. The first parameter is having a minimum of five single-subject studies published in peer-reviewed journals that meet the methodological criteria and demonstrate the existence of the experimental control. The second parameter is establishing that these five studies should have the authorship of at least three different researchers or groups of research located in three different geographic regions. The last parameter is to ensure that the studies have a minimum of 20 participants. In effect, the rigorous methodological process in the production of this evidence appears both relevant and necessary.

In this perspective, the purpose of the present study consisted of an effort, still in its early stage, to present evidence of the efficiency of the autoscopy procedure in training teachers and parents of children with autism. Consequently, although autoscopy may not have intervention as a primary goal, it has been deemed as a promising auxiliary procedure for teacher training in education. The national revisited studies on autoscopy using convenience sampling have shown that predominately qualitative studies, such as case studies (Larocca, 2002, Tosta, 2006; Rosa-Silva et al., 2009) or research-action (Campos \& Glat 2016) were used to verify its effects on the occupational practice. However, there is a lack of research that utilizes rigorous design, such as experimental or quasi-experimental, for this methodology to be analyzed as an independent variable, and, in doing so, contributing to present evidence that autoscopy may have significant effects in the context of teacher training. Therefore, the objective of this study was to verify the effect of autoscopy on the behavior of the agents administering the intervention (teachers and parents) in the educational practices with students with ASD. 


\section{Method}

\subsection{Research design and participants}

The study design uses a qualitative methodology of secondary data review (Heaton, 2004; Thorne, 2013). In this type of research methodology, the data of previous studies were re-analyzed for the purpose of refining or supplementing the original findings, as well as answering new research questions (Heaton, 2004; Thorne, 2013). The objective of this investigation was to refine the original findings of two studies that analyzed, among other variables, autoscopy as a methodological resource in interventions with autism. Both studies were selected by convenience sampling, and the autoscopy methodology was highlighted as the independent variable in these studies employing single -subject research design. The first was with the teachers Celia and Gloria (study A) and the second was with the parents of an autistic child (Study B). The objective of study A was to verify the effects of autoscopy on the pedagogical practices of two teachers that teach in multifunctional resource rooms with students with ASD (Silva, 2016). In study B, the effects of autoscopy were observed on the socio-communicative abilities of the mother and her son with ASD in the context of an intervention implemented by parents (Oliveira, 2016).

The dependent variables (DV) of each study consist of the intended target teacher behaviors. In study A, two DVs were connected to the behaviors of the teachers, specifically: 1. to improve the communication of the student, incentivizing the use of pictographic communication cards. In other words, these pictures were used by the teachers to elaborate questions and to establish some dialogue with their students, allowing them to express themselves. The second dependent variable was 2. to wait for the student's response. This dependent variable was essentially offering time necessary for the child to express himself utilizing the alternative communication resource in the instructional activities.

The DVs from study B were two sociocommunicative skills, 1. mother topic sharing. Mother topic sharing consists of gestures and/or verbal behavior used by the mother to share the topic with her child, engage the child in games/activities, as well as focus her attention on activities already initiated by the child, maintaining this interaction with objects and events. The second sociocommunicative skill is the 2. child's shared attention. This is characterized by the child's verbal and 
non-verbal behavior to initiate a/an activity/game, to share interests and discoveries, or to respond to the mother's stimuli.

Both of the studies conducted baseline sessions with video recordings of the agents of the intervention without the use of autoscopy $(A=3 ; B=4)$, followed by intervention sessions in which the videos were then seen and discussed with the participants $(A=4 ; B=12)$.

\subsection{Procedures and ethical consideration}

The studies were both submitted to the Ethics Committee of Research (ECR), with study A being approved by the ECR of Uerj ( $\mathrm{n} .336622$, of 2013, July $11^{\text {th }}$ ) and study $B$ by the ECR of UFSM (CAAE n. 49198115.2.0000.5346).

As far as the procedures were concerned, autoscopy was implemented in a standardized manner in both of the studies utilizing video analysis containing the intervention sessions of the participants. These were sent in advance to the researchers, followed by a discussion and analysis meeting of the participants with the researchers, focusing the dependent variables.

The baseline phase of study A was composed of by three 30-minute video recordings from the classes of two teachers (Célia and Glória) in multifunctional resource rooms; similarly study B relied on four 30-minute recordings of the child's free play with the mother, filmed by the father in their home. The agents of the intervention did the filming, specifically, the teachers of study $A$ and the father of study B. Subsequently, the recordings were sent to the researchers, without them having given any type of instruction or suggestion to the participants. After watching the videos, the researchers selected some scenes containing important situations, which would be discussed afterward in the intervention phase. The selected scenes had a length of 10 to 12 minutes in total. Subsequently, the videos delivered by the participants of the study were edited and cut, containing in its final version only the scenes that the researcher selected. In study $A$, the researcher with the two teachers collectively conducted the autoscopy sessions.

The intervention phase of the studies incorporated the beginning of the autoscopy procedure. The participants filmed the interventions, sent them to the researchers, who then made the selection of the scenes, which were going to be discussed in each of the autoscopy sessions. Then, parents and teachers returned to their interventions to create new recordings. In this dynamic, after each record- 
ing, a meeting was held about autoscopy. The sessions with the participants had, on average, a two-hour duration, in which teachers and parents were invited to look at how they conducted their interventions in the treatment of the students and the intervention with the child respectively. Such meetings were filmed and later transcribed. The objective was to analyze the speech of the participants after watching themselves work. At the time of the research, the participants received a direct orientation from the researchers, with the focus being to observe behaviors, which were the dependent variables of each study, as it was previously mentioned.

The two dependent variables of study A, corresponding to the frequency of teachers' responses, were collected utilizing a seven interval recording, each of them having a duration of three minutes, with a total of 21 minutes in each phase of the research. The dependent variables of study $B$, concerning the mother-child sociocommunicative abilities, were collected and analyzed for simple frequencies of each behavior.

To estimate the interobserver agreement on frequencies of the dependent variables, $25 \%$ of the sessions of each phase were randomly chosen. The protocols of the two independent observers were compared to establish the mean interobserver agreement indexes. For study A, 90\% (75-100\%) was obtained, and 75\% for study $B$, which, according to the researchers, represents a good rate for studies in this field of research.

Finally, the data from the studies were submitted to Tau-U, which is a method that evaluates the effect size of the intervention. It represents an index that analyzes single-subject research, which examines the non-overlap between phases with the data trends of the intervention phase. Also, it offers an option to control the trends of the baseline phase. Tau- $U$, measuring non-overlapping data between two phases (baseline and intervention), represents a non-parametric technique, which is called "free distribution," with statistical power ranging from $91 \%$ to $95 \%$ from the linear regression (OLS) when the data conform to the parametric assumptions. This statistical analysis is well adapted for small data series. Tau-U follows a sample distribution "S" (as well as the Kendall Tau Correlation Coefficient); however, the values of $\mathrm{p}$ and confidence intervals are available. Tau-U is a new calculation method, but it relies firmly on these two non-parametric methods (Parker, Vannest, Davis, \& Sauber, 2011). 


\section{Results}

Figure 3.1 ( $a$ and $b$ ) shows the frequencies of teachers using communication cards to encourage the communication of the students in the baseline and intervention phase.

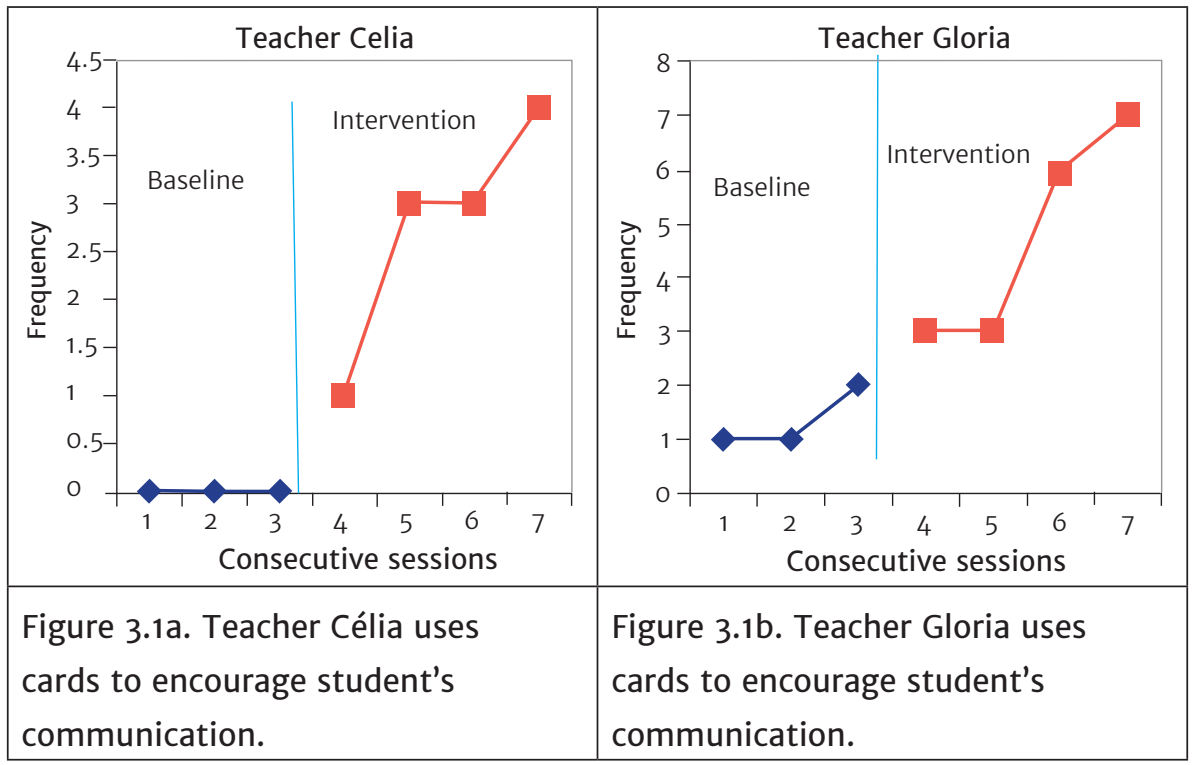

There is a clear growing trend in the frequency of behavior to encourage the communication of the student in the intervention phase.

Figure 3.2 ( $a$ and $b$ ) presents the frequencies of teachers Celia and Glória waiting for the students' response in the baseline and intervention.

Despite the variability, a growing trend is apparent in the frequency of the waiting behavior for both of the teachers. To exemplify such behaviors, such as offerings cards and waiting for the student's response, an excerpt from the $3^{\text {rd }}$ intervention session from the teacher Celia is transcribed below. 


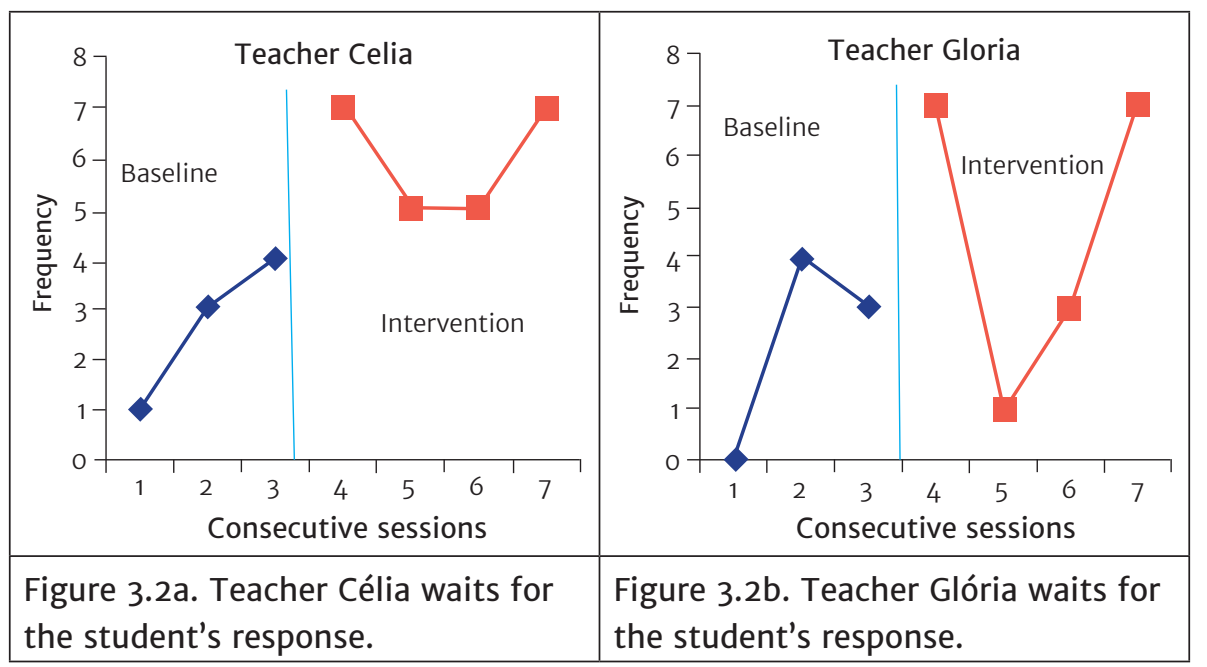

Teacher Celia: It is now snack time. Let us see what you will drink. She offers the students a board that contains two figures representing juice and water: What do you want? Show me what it is that you want to drink now. The teacher remains silent for a moment and waits for the response. The student takes the juice card and places it in the teacher's hand. She says: I understand. You want to drink the juice. Sit there, and I will grab it. The student smiles while she takes the juice. Celia notices the student's smile and says: Are you happy because you are drinking the juice that you selected? She points and grabs the picture card and says: You are happy today! You are laughing because you are happy. We are playing a lot with the bowling game that you chose, and now you chose the juice. It is because of this that you are happy! Congratulations and I am happy just like you. Look here at the happy card. The student looks at the card, smiles one more time, and finishes drinking the juice (Silva, 2016).

The teachers' responses were submitted and analyzed for their effect size, which was measured by Tau-U. The usage of the cards was to encourage the student's communication. Tau $-U$ revealed a $100 \%$ change from the baseline to the intervention, also revealing that it is statistically significant ( Tau-U $=1.00 / p=0.27)$. However, the teachers' behavior for waiting for the students' response exhibited a $70 \%$ change. It also reached a level of statistical significance (Tau-U $=0.783 / p$ $=0.0336)$. 
It turns out that both of the teachers' responses in the intervention phase showed strong effects from the autoscopy, attesting to its robustness. Therefore, we can affirm, with a probability above 95\% of accuracy, that the autoscopy procedures significantly affected the teachers' behavior both in the introduction of the alternative communication resources and in the waiting, that is, the provision of sufficient time for the student to respond.

It should be emphasized that this behavior of waiting on the teachers' part is a critical strategy in teaching communication. This is well-documented in the scientific literature, either with small children or with nonverbal individuals. Therefore, the trend in the dialogues with these individuals who do not speak is for the adult to initiate and control the interaction, anticipating their wishes, and not offering enough time for them to respond. In the present study, during the baseline phase, it was noticed that the teachers began the interaction with their students, but rarely waited for their responses.

As for the results of study B, Figure 3.3 represents the frequency of the maternal behavior (Mother Topic Sharing) and the child (Attention Sharing) during the baseline and intervention phases.

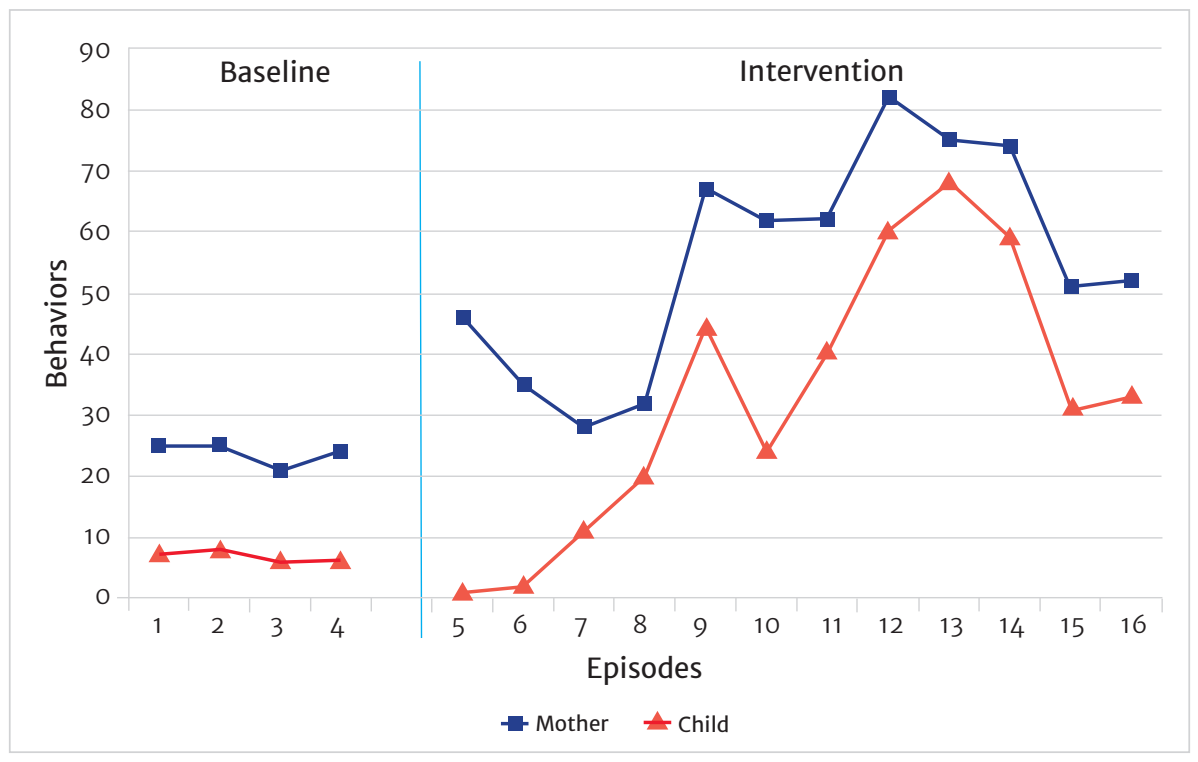

Figure 3.3. Frequency of Shared Topic and Shared Attention behaviors. 
Stability was observed in the baseline phase, followed by a growing trend in the frequency of sociocommunicative behavior of the pair from the intervention phase.

The child's shared attention behavior obtained a 66\% change, which can be considered borderline but still statistically significant ( $T a u-U=0.66 / p=0.05223$ ). The effect size of the intervention of the maternal behavior of the shared topic showed a $100 \%$ change in the intervention phase in comparison to the baseline phase. Despite not being able to confirm the statistical validity of the experiment, due to the $p$-value being larger than 0.5 , we must consider the clinical validity, obtained by the growth curve in the intervention phase $(\mathrm{Tau}-U=1.00 / \mathrm{p}=0.00036)$. This data confirmed that the autoscopy wielded significant effects on the frequency of both the mother and child's behaviors.

\section{Discussion}

Two of the quasi-experimental single-subject research studies aimed to verify the effect of autoscopy on the behavior of the agents involved in the intervention (teachers and parents) in educational practices with students with ASD. The conclusions indicate that autoscopy as a methodological resource is capable of wielding significant effects on the behavior of the agents of the intervention.

It should be highlighted that the essential step of autoscopy is the incorporation of the analysis of the material filmed to learn about the reflective process of the agents of the intervention by utilizing their verbalizations during the presentation of the video-recorded scenes. Therefore, in study $A$, in the intervention phase, it was proposed that the teachers reflect on their performance presented in the video in order to stimulate their sensibility to perceive the challenges that emerge from the teaching reality. Initially, the teachers had difficulty in recognizing the need to change their practices and positions. Their planning was rigid, with little possibility of reflection on their routine and proposed activities.

Gradually, the teachers complied with the self-analysis, as well as the reflective process of the research for their pedagogical practices, ultimately switching places from their positions as teachers to that of the student. The experience of the first session of the intervention phase of teacher Célia with her student illustrates such an attitude. The scene begins with the teacher demonstrating three cups numbered 1 to 3 and a bowl with twist-off bottle lids to the student. The activity 
consisted of identifying the number of cups and placing in them the correct quantity of corresponding lids:

Teacher Célia says: Listen to what we are going to do - showing a box with lids. The student plays with the doll and does not look at the teacher. She says: No, it is not the doll. Look, at these pieces here. Do you see? We have lids. The student continues playing with the doll, without paying attention to the teacher. The teacher shows the cups to the student and says: Let us place the lids here inside. The student insists on playing with the doll, and the teacher takes the toy from the child's hands. The student grabs the box with the lids, and the teacher says: Like this, you will topple them [...] Will you let me help you? First, let us stop the defiance and after, we will do it correctly. The student places the lids inside the cup in an indiscriminate manner and allows the cups to fall to the ground. Teacher Célia: Can you put everything away because I do not want to do this anymore? This is not how it is supposed to be. Do you see how everything is all messed up? No, it is not even the time to play. I know that you want to play with the doll, but I already said no! (Silva, 2016).

Upon observing the scene and initiating the reflective process, teacher Célia claimed that this day had been the first day in which she had been alone with the student using this as a justification as to why she still had not been accustomed to the routine and did not respect her command. After hearing what she said, the researcher persisted while trying to make the student continue the activity that, ostensibly, he did not agree with. Upon hearing such a critique, the other teacher, Glória, questioned the limit between insisting that a student do something and allowing him or her to choose to complete the activity or not. Teacher Célia agreed with the position taken by her colleague and added that wavering on the activity is "to give leeway to the student to do only what he or she may have interest and desire to do."

The reported scene and the comments made by the teachers demonstrated that they maintained the practice of teacher-centered learning, in which teaching is done inflexibly, without space for the students to express themselves. This teacher's attitude can be the reason as to why the students show little effort in communicating. In some of the situations, it was possible to perceive that the stu- 
dents were able to demonstrate initiatives in communication. In some cases, they even displayed signs of their specific interests, but the response that the teachers gave them, the majority of the times, were negations of their requests and, with that, the teachers lost the opportunity to stimulate the autonomy of the students. When the teacher says something such as "I know that you want to play with the toy, but I already said no," she does not create the possibility for the student to express himself or herself because there is no justification for the teacher to reject the student's wishes

In the final step, the teachers were invited to share their experiences after observing themselves in the videos. The observation of their responses provides an important dimension in the critical-reflexive practice, which then allows for a transformation in the attitude and teaching method. Teacher Célia responded to the first question in tears. She was emotional after recounting how difficult this process was for her to be observed in her daily practices. Teacher Célia cried after describing her observation of her actions, which made her perceive that it is necessary to change every day and that we cannot always stay the same:

Teacher Célia: At the beginning of the research proposal I was very excited but then became depressed, I got sad, and I thought: "Darn, what was I doing with this boy?", [...] "Why am I holding lids if the boy doesn't even like lids?" [...] Little by little, I began to perceive that the practice is broader than what I was focusing on. [...] This is good for us to get shaken up a bit. I thought: "Do you see how there is no use in doing undergraduate research? If you do not change your practice, your theoretic knowledge has no use. And if it wasn't for your research and the opportunity that I had to see myself through the videos, maybe I would still be doing the same old thing with the lids even now" (Silva, 2016).

The teacher's statement caused a large impact on the research team when they perceived how the adopted procedures could contribute to the teachers' personal and professional development. The autoscopy sessions highlighted the importance of training based on the process of self-analysis. This self-evaluation utilizing videos gave the teachers the desire to reevaluate their pedagogical techniques from the confrontation created between the depicted image and the daily experiences of the classroom. 
Similarly to Study A, the autoscopy procedures used in Study B, the parents with their children with autism, also aimed at improving the reflective process of the parent regarding their behavior during the intervention with the child. In this case, the videos of the baseline phase showed that mother was more anxious during the play session, using small toys to interact with the child and directing her strategies almost exclusively to trying to develop the speech of the child, requesting verbal responses.

At the beginning of the intervention phase, the mother was shown videos of herself and her son during the intervention to reflect on what was happening in the scene. Initially, the mother described the anxiety she had of her son's speech delay, explaining his difficulty in maintaining interaction without a response on her son's part. Researchers have pointed out that difficulties with communication, which are central to autism, is broader than speech, and includes things such as facial expressions and gestures to maintain interaction.

It was highlighted that there was a maternal inadequacy in terms of the utilization of other resources that engaged the child in games. The mother identified and recognized her inability in establishing exchanges with the child that was not through verbal initiatives, understanding that she was only able to broaden the development of communication by the development of speech. According to the mother, this was the reason for her anxiety in the interventions. From that point on, the researchers suggested incorporating toys, which the child enjoys in the interventions, so that the mother could use more non-verbal strategies, such as pointing and showing, to regulate the interaction.

Throughout the next sessions, the mother continued to get the son's attention with verbal cues; however, it was perceived that the dyad was more engaged when she showed the toy and played with the child. Consequently, the frequency of the maternal topic-sharing behaviors increased, to which the shared attention of the child also remained more evident and frequent. During the subsequent sessions, the mother described that she was indeed nervous while seeing that she only concentrated on the child's communication difficulties, that is, the absence of verbal language. She received little response from the child and consequently gave little attention to his other non-verbal abilities such as visual exchanges and the use of pointing. In this regard, it was proposed, by the mother's initiative, to play with paint during the intervention and, on another day, playdough, using the area 
of the face to obtain the largest visual contact with the child. The following description illustrated the success obtained by the adoption of these strategies from the mother "[...] I am happier in seeing my performance through the videos and also in knowing how to better behave towards my child, establishing more visual contact as a form of interaction."

With these illustrations of the autoscopy practices, it is possible to understand the scope of this strategy in different interventions in the area of autism. The oriented reflection process showed how to generate changes in the behavior of the participants, directly affecting the form and the effectiveness of the intervention.

In conclusion, the use of autoscopy and self-confrontation offers an opportunity to develop an awareness of what Vygotsky says is a generalization: "...to perceive things in another way is, at the same time, to acquire other possibilities of action concerning them [...]. Generalizing my own process, I acquire the possibility of creating another relation with it" (Vygotsky, 1989).

\section{References}

Allan, M. (1968). Teaching English with video. Harlow-England: Longman Group Limited. American Psychiatric Association (2013). Diagnostic and Statistical Manual of Mental Disorders. (DSM-5). Washington: American Psychiatric Association.

Campos, K. P. B., \& Glat, R. (2016). Procedimentos favoráveis ao desenvolvimento de uma criança com Síndrome de Down numa classe comum. Revista Educação Especial, 1(1), 26-40. doi:10.5902/1984686X10399

Chizzotti, A. A. (2015). Pesquisa educacional e o movimento "pesquisas científicas baseadas em evidências". Práxis Educativa, 10(2), 329-342. Recuperado de http:// www.revistas2.uepg.br/index.php/praxiseducativaHeaton, J. (2004). Reworking qualitative data. London: Sage.

Horner, R. H., Carr, E. G, Halle, J., McGee, G., Odom, S., \& Wolery, M. (2005). The use of single-subject research to identify evidence-based practice in special education. Exceptional Children, 71(2), 165-179. doi:10.1177\%2Fo01440290507100203

Larocca, P. (2002). Psicologia e prática pedagógica: o processo de reflexão de uma professora (Tese de doutorado, Universidade Estadual de Campinas). Recuperado de http:// ri.uepg.br/riuepg/handle/123456789/911 
Nunes, D. R., \& Nunes, F. P. Sobrinho (2010). Comunicação alternativa e ampliada para educandos com autismo: Considerações metodológicas. Revista Brasileira de Educação Especial, 16(2), 297-293. doi:10.1590/S1413-65382010000200010

Oliveira, J. J. M. (2016). Intervenção centrada na família: influência nas habilidades comunicativas e interativas da criança com transtorno de espectro autista e no empoderamento parental. (Dissertação de mestrado, Universidade Federal de Santa Maria). Recuperado de https://repositorio.ufsm.br/handle/1/7261

Parker, R., Vannest, K., Davis, J., \& Sauber, S. B. (2011). Combining nonoverlap and trend for single-case research: Tau-U. Behavior Therapy, 42(2), 284-299. doi:10.1016/j. beth.2010.08.006

Perez, D., \& Messias, C. (2013). O dispositivo metodológico e interventivo: Autoconfrontação e seus usos em pesquisas em Educação. Nuances: estudos sobre Educação, 24(3), 81-100. doi:10.14572/nuances.v24i3.2699

Pletsch, M. D., \& Souza, F. F. (2017). Fórum Permanente de Educação Especial da Baixada Fluminense: Pesquisa e extensão na formação de professores. Inclusão Social, 11(1), 46-55. Recuperado de http://revista.ibict.br/inclusao/article/view/4078/3590

Rosa-Silva, P. O, Lorencini, A. Júnior, \& Laburú, C. E. (2009). A autoscopia como estratégia da sala de espelhos na formação continuada de uma professora de ciências. VII Encontro Nacional em Pesquisa em Educação em Ciências. Florianópolis, novembro 2009. Recuperado de http://www.posgrad.fae.ufmg.br/posgrad/viienpec/pdfs/1430.pdf

Sadalla, A. M. F. A., \& Larocca, P. (2004). Autoscopia: um procedimento de pesquisa e de formação. Educação e Pesquisa, 30(3), 419-433.

Schmidt, C., Ramos, F., \& Bittencourt, D. (2019). Intervenção mediada por pares como prática pedagógica para alunos com autismo. In: A. C. Pavão \& S. M. O. Pavão, (Orgs.), Práticas Educacionais Inclusivas na Educação Básica (pp. 87-104). Santa Maria: Facos UFSM. Recuperado de https://www.ufsm.br/orgaos-executivos/caed/wp-content/ uploads/sites/391/2018/12/Educa\%C3\%A7\%C3\%A30-B\%C3\%A1sica.pdf?fbclid= IwAR33bHKK1I5snruA6eBYLLKAJB3ul3aiFyxcww5VJy_c9YvnUqzlxVpj_u8

Schön, D. A. (2000). Educando o profissional reflexivo: Um novo design para o ensino e a aprendizagem. Porto Alegre: Artes Médicas Sul.

Silva, T. M. (2016). A Autoscopia como ferramenta para a formação continuada de professores de Sala de Recursos Multifuncionais. (Dissertação de mestrado, Universidade Estadual do Rio de Janeiro). Recuperado de http://www.proped.pro.br/teses/teses_pdf/2014_ 1-1250-ME.pdf 
Silva, T. M., \& Nunes, L. R. O. P. (2017). O uso da autoscopia como aliada na formação continuada de professores de Salas de Recursos Multifuncionais. In: L. R. O. P. Nunes \& C. R. Schirmer (Orgs.), Salas abertas: formação de professores e práticas pedagógicas em comunicação alternativa e ampliada nas salas de recurso multifuncionais. (pp.131-162). Rio de Janeiro: EdUERJ. Recuperado de http://books.scielo. org/id/xns62

Tassoni, E. C. M. (2008). A dinâmica interativa na sala de aula: As manifestações afetivas no processo de escolarização. (Tese de doutorado, Universidade Estadual de Campinas). Recuperado de http://repositorio.unicamp.br/jspui/handle/REPOSIP/251875

Thorne, S. (2013). Secondary qualitative data analysis. In C. T. Beck (Ed.), Routledge International Handbook of Qualitative Nursing Research (pp. 393-404). New York: Taylor \& Francis.

Tosta, C. G. (2006). Autoscopia e desenho: A mediação em uma sala de educação infantil (Dissertação de Mestrado não publicada, Universidade Federal de Uberlândia). Recuperado de https://repositorio.ufu.br/handle/123456789/17176

Vygotsky, L. S. (1989). Pensamento e Linguagem. São Paulo: Martins Fontes.

Zeichner, K (1994). Action research and issues of equity and social justice in preservice teacher education. New Orleans: Anual Meeting of the American Education Research Association.

\section{Authors notes}

Carlo Schmidt, Graduate Program in Education, Federal University of Santa Maria (UFSM); Leila Regina O. de P. Nunes, Graduate Program in Education, State University of Rio de Janeiro (Uerj); Thatyana M. Silva, Graduate Program in Education, State University of Rio de Janeiro (Uerj); Jéssica Jaíne $\mathbf{M}$. de Oliveira, Graduate Program in Education, Santa Maria Integrated College (FISMA).

Correspondence concerning this article should be addressed to Carlo Schmidt, Rua Silva Jardim, 213/405, Porto Alegre, RS, Brazil. CEP 90450-071.

E-mail: carlo.schmidt@ufsm.br 